\title{
Apical ballooning of the left ventricle: first series in white patients
}

\author{
W J R Desmet, B F M Adriaenssens, J A Y Dens
}

See end of article for authors' affiliations

Correspondence to: Dr Walter Desmet, UH Gasthuisberg, Cardiology Department, Herestraat 49 B 3000 Leuven, Belgium;

Walter.Desmet@

uz.kuleuven.ac.be

Accepted 20 March 2003

\begin{abstract}
Background: A cardiac syndrome of "apical ballooning" was recently described, consisting of an acute onset of transient extensive akinesia of the apical and mid portions of the left ventricle, without significant stenosis on the coronary angiogram, accompanied by chest symptoms, ECG changes, and a limited release of cardiac markers disproportionate to the extent of akinesia. Until now, this syndrome has been reported only in Japanese patients.

Objective: To describe 13 white patients who presented with this syndrome over the previous four years.

Results: All but one of the patients were women with a mean age of 62 years. Eight of them presented with chest pain, of whom six had cardiogenic shock. In nine patients a triggering factor was identified: emotional stress in three, trauma in one, pneumonia in one, asthma crisis in one, exercise in two, and cerebrovascular accident in one. In all patients left ventriculography showed very extensive apical akinesia ("apical ballooning") in the absence of a significant coronary artery stenosis, not corresponding with the perfusion territory of a single epicardial coronary artery. Mean maximal creatine kinase MB and troponin rise were $27.4 \mu \mathrm{g} / \mathrm{l}$ (range 5.2-1 $15.7 \mu \mathrm{g} / \mathrm{l}$, median $16.6 \mu \mathrm{g} / \mathrm{l}$ ) and $18.7 \mathrm{\mu g} / \mathrm{l}$ (range $2.0-97.6 \mu \mathrm{g} / \mathrm{I}$, median $14.5 \mathrm{\mu g} / \mathrm{l})$, respectively. Six patients were treated with intra-aortic balloon counterpulsation. One patient died of multiple organ failure. On necropsy, no myocardial infarction was found. In the 12 survivors, left ventricular systolic function recovered completely within three weeks.

Conclusions: This is the first series of "apical ballooning" to be reported in white patients. Despite dramatic initial presentation, left ventricle function recovered completely within three weeks in the sur-
\end{abstract} vivors.
$\mathrm{R}$ ecently a series of 88 patients with a syndrome of left ventricular apical ballooning without coronary artery stenosis was presented. ${ }^{1}$ The syndrome consists of an acute onset of transient extensive akinesia of the apical and mid portions of the left ventricle, without significant stenosis on the coronary angiogram, accompanied by chest symptoms, ECG changes, and a limited release of cardiac markers disproportionate to the extent of akinesia. So far this syndrome was described only in Japanese patients and the question arose whether this syndrome existed outside Japan..$^{2-7}$ We present a study of 13 patients all meeting the postulated criteria. Clinical presentation, precipitating factors, ECG changes, laboratory values, and medical imaging are presented. To give a good view of the clinical presentation two typical cases are described. This article provides the first description of this novel heart syndrome in white patients.

\section{METHODS}

We describe 13 white patients who presented with this novel heart syndrome at our institution over the past four years: one in 1998, four in 2001, and eight in 2002. The following parameters were evaluated: sex, age, presenting symptoms and duration of symptoms before admission, serial ECGs, QT interval, cardiac enzymes, cardiac imaging, invasive pressures, cardiac index and wedge pressure, the use of intra-aortic balloon counterpulsation, pathological findings, and parameters of recuperation.

\section{RESULTS}

\section{Case reports}

Case 1 (patient 5)

A 48 year old woman with a history of haemochromatosis presented to the emergency department with a four hour his- tory of chest discomfort, dyspnoea, and palpitations. The ECG on admission showed slow $\mathrm{R}$ progression in the precordial leads. Subsequently she developed negative $\mathrm{T}$ waves in the anterolateral leads.

The troponin I, creatine kinase (CK), and $\mathrm{CK} M B$ concentrations were slightly increased (table 1).

Over the following hours she developed haemodynamic instability with evolution to cardiogenic shock. An emergency echocardiography showed anteroapical akinesia. Left ventriculography confirmed the presence of a large anteroapical akinetic zone with a severe decrease of left ventricular ejection fraction $(30 \%)$. No intraventricular pressure gradient was observed. Coronary angiography showed normal coronary arteries. Intra-aortic balloon counterpulsation was initiated and intravenous inotropic drugs were administered.

On endomyocardial biopsies, there was no evidence of haemochromatosis, sarcoidosis, myocarditis, or vasculitis.

After 12 days the patient made a complete functional recovery, with normalisation of the wall motion and global left ventricular systolic function on echocardiographic evaluation.

\section{Case 2 (patient 2)}

A 78 year old woman with restrictive lung disease caused by a congenital diaphragmatic hernia with superimposing corticoid dependent obstructive lung disease was admitted after a fall with two rib fractures. She was transferred to the coronary care unit because of ST elevations seen on monitoring. Twelve lead ECG had clearly changed and showed ST elevation of $7 \mathrm{~mm}$ in leads V2 and V3 and of $2 \mathrm{~mm}$ in V4, as well as discrete ST segment elevations in leads I and aVL. The patient had no thoracic pain but was receiving an infusion of tramadol for pain caused by her rib fractures. She complained only of increasing dyspnoea. 
Table 1 Findings in 13 white patients with "apical ballooning"

\begin{tabular}{|c|c|c|c|c|c|c|c|c|c|c|c|c|c|}
\hline & \multicolumn{13}{|l|}{ Patient number } \\
\hline & 1 & 2 & 3 & 4 & 5 & 6 & 7 & 8 & 9 & 10 & 11 & 12 & 13 \\
\hline Sex & $\mathrm{F}$ & $\mathrm{F}$ & $\mathrm{F}$ & $\mathrm{F}$ & $\mathrm{F}$ & $\mathrm{F}$ & $\mathrm{F}$ & $\mathrm{F}$ & $\mathrm{F}$ & $\mathrm{F}$ & M & $\mathrm{F}$ & $\mathrm{F}$ \\
\hline Age (years) & 81 & 78 & 65 & 71 & 48 & 66 & 52 & 48 & 45 & 66 & 57 & 60 & 69 \\
\hline Presenting symptom & Chest pain & $\begin{array}{l}\text { ST } \uparrow \\
\text { on monitor }\end{array}$ & $\begin{array}{l}\text { Chest pain, } \\
\text { vomitus }\end{array}$ & $\begin{array}{l}\text { Chest pain, } \\
\text { dyspnoea }\end{array}$ & $\begin{array}{l}\text { Chest pain, } \\
\text { shock }\end{array}$ & $\begin{array}{l}\text { Chest pain, } \\
\text { vomitus }\end{array}$ & CVA, fall & $\begin{array}{l}\text { Dyspnoea, } \\
\text { cough }\end{array}$ & VF & Chest pain & $\begin{array}{l}\text { Respiratory } \\
\text { distress }\end{array}$ & $\begin{array}{l}\text { Chest pain, } \\
\text { dyspnoea }\end{array}$ & $\begin{array}{l}\text { Chest pain, } \\
\text { dyspnoea, } \\
\text { nausea }\end{array}$ \\
\hline $\begin{array}{l}\text { Duration before } \\
\text { admission (h) }\end{array}$ & 24 & 0 & 5 & 4 & 6 & 5 & 2 & NA & 0 & 36 & NA & 7 & 26 \\
\hline $\begin{array}{l}\text { Symptoms before TTE } \\
\text { (h) }\end{array}$ & 24 & 6 & 72 & 24 & 16 & 11 & 48 & 68 & 50 & 24 & 48 & 18 & 68 \\
\hline $\begin{array}{l}\text { Symptoms before } \\
\text { angiography (h) }\end{array}$ & 26 & 2 & 16 & 6.5 & 10 & 19 & 12 & 72 & 2.6 & 27 & 3 & 24 & 3 \\
\hline Precipitating factor & Unknown & $\begin{array}{l}\text { Trauma (rib } \\
\text { fractures) }\end{array}$ & $\begin{array}{l}\text { Emotional stress } \\
\text { (death of } \\
\text { husband) }\end{array}$ & Unknown & $\begin{array}{l}\text { Emotional } \\
\text { stress }\end{array}$ & Unknown & CVA & $\begin{array}{l}\text { Asthma } \\
\text { crisis }\end{array}$ & Unknown & Exercise & $\begin{array}{l}\text { Aspiration } \\
\text { pneumonia }\end{array}$ & $\begin{array}{l}\text { Emotional } \\
\text { stress (minor } \\
\text { car accident) }\end{array}$ & Exercise \\
\hline Admission ECG & Normal & Normal & Normal & $\begin{array}{l}\text { Negative T } \\
\text { V1-V6, ST } \uparrow \\
\text { V1-V4 }\end{array}$ & $\begin{array}{l}\text { Slow R } \\
\text { progression } \\
\text { anterior, ST } \uparrow \\
\text { V1-V6 }\end{array}$ & LBBB (new) & Normal & Normal & $\begin{array}{l}\text { Negative T II, } \\
\text { III, aVF }\end{array}$ & $\begin{array}{l}\text { Negative TI, } \\
\text { II, aVL, aVF, } \\
\text { V3-V6 }\end{array}$ & $\begin{array}{l}\text { ST } \uparrow \text { I, II, aVF, } \\
\text { V2-V6 }\end{array}$ & $\mathrm{ST} \uparrow \mathrm{I}, \mathrm{aVL}$ & $\begin{array}{l}\text { Discrete ST } \uparrow \\
\text { II, III, aVF, } \\
\text { V2-V6 }\end{array}$ \\
\hline ECG on day 1 & $\begin{array}{l}15 \text { min later, } \\
\text { broad QRS after } \\
\text { resuscutation }\end{array}$ & $\begin{array}{l}12 \mathrm{~h} \text { later, } \\
\text { negative T } \\
\text { V1-V6, ST } \uparrow \\
\text { V2-V6 }\end{array}$ & Normal & Unchanged & $\begin{array}{l}4 \mathrm{~h} \text { later, } \\
\text { ST } \uparrow \text { more } \\
\text { pronounced }\end{array}$ & $\begin{array}{l}8 \mathrm{~h} \text { later, } \\
\text { negative T } \\
\text { V4-V6, aVL }\end{array}$ & $\begin{array}{l}12 \mathrm{~h} \text { later, ST } \\
\text { increase } 1 \mathrm{~mm} \\
\text { and negative T } \\
\text { V2-V6 }\end{array}$ & $\begin{array}{l}48 \text { h later, } \\
\text { negative T } \\
\text { V2-V6, II, } \\
\text { III, aVF }\end{array}$ & $\begin{array}{l}\text { Negative TI, } \\
\text { III, aVF, V3, } \\
\text { V6 }\end{array}$ & $\begin{array}{l}8 \mathrm{~h} \text { later } \\
\text { unchanged }\end{array}$ & $\begin{array}{l}\mathrm{ST} \uparrow \| \mathrm{I}, \mathrm{aVL}, \\
\text { negative TI, } \\
\text { aVL, V2-V6 }\end{array}$ & $\begin{array}{l}\text { ST } \uparrow I, \text { aVL, } \\
\text { negative TI, } \\
\text { aVL, V2-V6 }\end{array}$ & NA \\
\hline ECG on day 2 & $\begin{array}{l}\text { Negative T } \\
\text { V2-V6, I, II, III, } \\
\text { aVF, ST } \uparrow 0.5 \mathrm{~mm} \\
\text { III, aVF }\end{array}$ & Unchanged & $\begin{array}{l}\text { Negative T } \\
\text { V3-V6 }\end{array}$ & Unchanged & $\begin{array}{l}\text { Negative T } \\
\text { V3-V6, II, III, } \\
\text { aVF, ST } \uparrow \\
\text { V3-V5 }\end{array}$ & Unchanged & $\begin{array}{l}\text { Deep negative } \\
\text { T anterior, I, II, } \\
\text { aVL, aVF }\end{array}$ & Unchanged & $\begin{array}{l}\text { Negative T } \\
\text { V2-V6 more } \\
\text { pronounced, } \\
\text { negative TII, } \\
\text { aVF }\end{array}$ & $\begin{array}{l}\text { Negative T } \\
\text { V3-V6 }\end{array}$ & $\begin{array}{l}\text { ST } \uparrow \| I, \text { aVL, } \\
\text { negative TI, } \\
\text { aVL, V2-V6 }\end{array}$ & $\begin{array}{l}\text { Negative T I, } \\
\text { aVL, V2-V6 } \\
\text { more } \\
\text { pronounced }\end{array}$ & NA \\
\hline ECG follow up & NA & Negative T & Negative T & Normal & Normal & Normal & Negative T & Negative T & Negative T & $\begin{array}{l}\text { Negative T } \\
\text { aVL }\end{array}$ & $\begin{array}{l}\text { Flattened T } \\
\text { waves }\end{array}$ & $\begin{array}{l}\text { Slightly } \\
\text { negative T I, } \\
\text { aVL, V3-V6 }\end{array}$ & Normal \\
\hline Pathological $Q$ waves & V1-V3 & Anterior & Absent & Absent & Absent & Absent & V1-V3 & V1-V3 & Absent & Absent & Absent & Absent & Absent \\
\hline QTc (ms) & 460 & 428 & 674 & 466 & 522 & 441 & 310 & 434 & 400 & 469 & 436 & 406 & 409 \\
\hline $\begin{array}{l}\text { Admission CK MB } \\
(\mu \mathrm{g} / \mathrm{ml})\end{array}$ & NA & NA & 16.6 & 10.9 & 16.2 & NA & 5 & 5.2 & 4.7 & 11.8 & 40.5 & 12.4 & 12.1 \\
\hline $\begin{array}{l}\text { Maximum CK MB } \\
(\mu \mathrm{g} / \mathrm{ml})\end{array}$ & 34.9 & 32.5 & 16.6 & 10.9 & 16.2 & 42 & 17.5 & 5.2 & 6.3 & 11.8 & 115.7 & 34.5 & 12.1 \\
\hline $\begin{array}{l}\text { Admission troponin I } \\
\text { ( } \mathrm{gg} / \mathrm{ml})\end{array}$ & 10.1 & 13.4 & 17.8 & 17.3 & 19.4 & NA & 1.9 & $<0.12$ & 3.4 & 5.7 & 14.0 & 2.2 & 3.6 \\
\hline $\begin{array}{l}\text { Maximum troponin I } \\
(\mu \mathrm{g} / \mathrm{ml})\end{array}$ & 97.6 & 16.9 & 17.8 & 17.3 & 19.4 & NA & 12.1 & 2.0 & 3.4 & 5.7 & 23.2 & 5.6 & 3.6 \\
\hline IPG (mm Hg) & 0 & 0 & 0 & 0 & 0 & 90 & 0 & 0 & 0 & 79 & 0 & 0 & 0 \\
\hline LVEDP (mm Hg) & 20 & 35 & 20 & 24 & 34 & 18 & 42 & 24 & 28 & 34 & 30 & 20 & 22 \\
\hline Cardiac index & 1.7 & NA & NA & NA & 1.3 & 1.7 & NA & NA & 2.2 & NA & 2.2 & NA & NA \\
\hline PCWP (mm Hg) & 9 & NA & NA & NA & 8 & 16 & NA & NA & 18 & NA & 23 & NA & NA \\
\hline IABP (days) & 5 & None & None & None & 4 & 4 & None & None & 5 & 2 & 5 & None & None \\
\hline $\begin{array}{l}\text { Endomyocardial } \\
\text { biopsy }\end{array}$ & NA & NA & NA & NA & Normal & NA & NA & NA & NA & NA & NA & NA & NA \\
\hline NYHA & NA & $\|$ & 1 & 1 & 1 & $\|$ & ॥ & 1 & 1 & $\|$ & ॥ & 1 & $\|$ \\
\hline $\begin{array}{l}\text { Time to recuperation } \\
\text { (days) }\end{array}$ & NA & 9 & 14 & 18 & 12 & 14 & 14 & 35 & 12 & 46 & 26 & 15 & 15 \\
\hline
\end{tabular}

CK, creatine kinase; CVA, cerebrovascular accident; F, female; IABP, intra-aortic balloon pump; IPG, intraventricular pressure gradient; LBBB, left bundle branch block; LVEDP, left ventricle end diastolic pressure; M, male; NA, not available; NYHA, New York Heart Association functional class at discharge; PCWP, pulmonary capillary wedge pressure; TTE, transthoracic echocardiography; VF, ventricular fibrillation. 

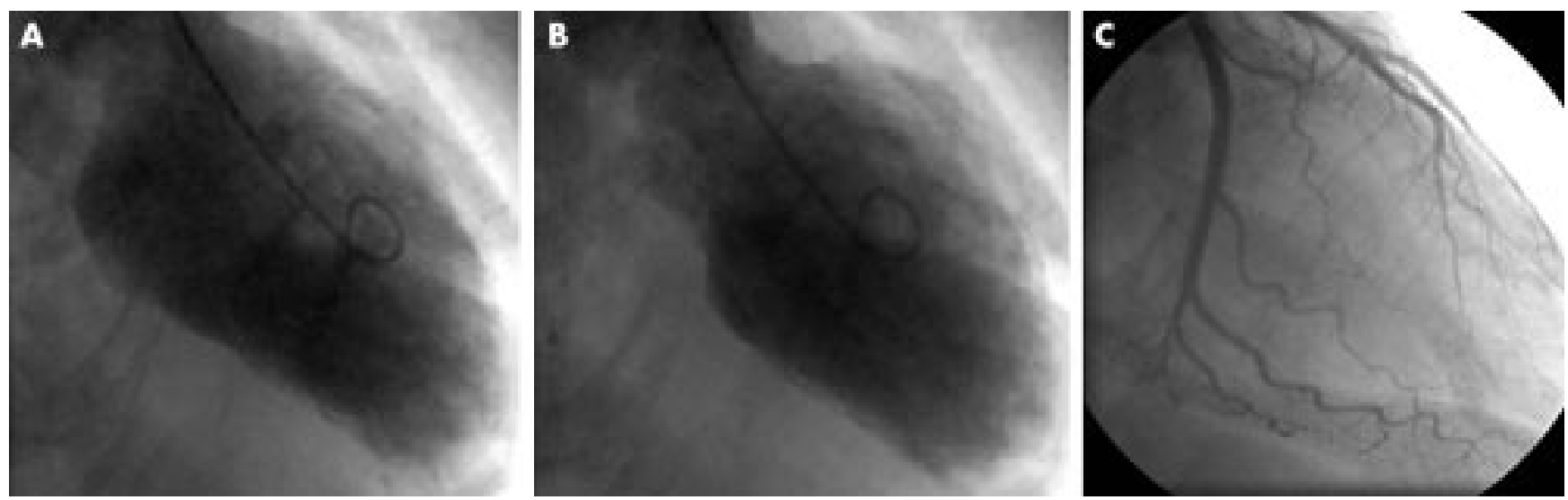

Figure 1 End diastolic (A) and end systolic (B) left ventriculograms of patient 9 show extensive akinesia of the apical and mid portions of the left ventricle, representative of all patients in the present series. On coronary angiography (C) no coronary artery stenoses were seen. The distal end of the left anterior descending artery does not reach the apex.

An urgent coronary angiography was performed. Surprisingly this showed normal coronary arteries but a severely affected systolic function: only the basal parts of the heart had normal contractility, and a large apical portion was akinetic. End diastolic left ventricular pressure was $35 \mathrm{~mm} \mathrm{Hg}$. Ejection fraction was $36 \%$. The same characteristics of normal basal contractility and severely reduced apical contractility were documented by magnetic resonance imaging afterwards. Biochemically there was a slight rise in cardiac markers: troponins rose to $17 \mu \mathrm{g} / \mathrm{l}$ (normal $<0.6 \mu \mathrm{g} / \mathrm{l}$ ). Treatment was conservative with diuretics and oxygen. Treatment with an angiotensin converting enzyme inhibitor was initiated. In the following days, systolic function improved gradually. A control transthoracic echocardiography showed normalisation of the regional contractility on day 10

\section{Clinical findings}

All but one of the patients were women, with a mean age of 62 years (table 1). Only one patient had a history of angina-like complaints. The clinical presentation in our series varied from mere ECG abnormalities to chest pain, dyspnoea, and even ventricular fibrillation or evolution to cardiogenic shock. Eight of the 13 patients presented with chest pain, of whom six had cardiogenic shock. In nine patients possible triggering by a major physical or emotional impact was identified: severe emotional stress in three, exercise in two, and trauma, an asthma crisis, pneumonia, and a cerebrovascular accident in one patient each.

The ECG on admission was normal in five patients. In another five patients slight to pronounced ST segment elevation was noted in multiple anterior leads. Two patients presented with negative T waves and one with a new left bundle branch block. In all patients negative $\mathrm{T}$ waves in the anterior leads developed over the following days. After a mean of three weeks, the ECG had normalised in four patients and in the others negative $\mathrm{T}$ waves persisted, up to one year in one patient.

In the acute phase, 12 of the 13 patients had a QTc interval of at least $400 \mathrm{~ms}$ (range 310-674 ms, mean $450 \mathrm{~ms}$, median $436 \mathrm{~ms}$ ).

Maximum troponin I concentrations ranged from 2.0 to $97.6 \mu \mathrm{g} / \mathrm{l}$ (mean $18.7 \mu \mathrm{g} / \mathrm{l}$, median $14.5 \mu \mathrm{g} / \mathrm{l}$ ). The MB fraction of CK rose moderately in all patients (range 5.2-115.7 $\mu \mathrm{g} / \mathrm{l}$, mean $27.4 \mu \mathrm{g} / \mathrm{l}$, median $16.6 \mu \mathrm{g} / \mathrm{l}$ ).

In all patients, echocardiography exhibited akinesia of the apical and mid portions of the left ventricle. The same pattern of contractility was observed on magnetic resonance imaging in three patients.

Because of the clinical presentation and the ECG changes, a severe ischaemic event was suspected and coronary angiography was performed in all patients between $2-72$ hours after the onset of symptoms (mean 17 hours, median 12 hours). In patients who were not in cardiogenic shock, $100 \mu \mathrm{g}$ glyceryl trinitrate intracoronarily was administered. Five patients had completely normal coronary arteries. In the others minor stenoses were seen, estimated to be $<25 \%$ diameter stenosis in all cases. A large apical portion of the left ventricle was akinetic or dyskinetic, whereas basal contractility was normal or even supernormal (fig 1) End diastolic pressures were increased (mean $27 \mathrm{~mm} \mathrm{Hg}$, minimum $18 \mathrm{~mm} \mathrm{Hg}$, maximum $42 \mathrm{~mm} \mathrm{Hg}$ ). In the six patients who received intra-aortic balloon counterpulsation, a Swan-Ganz catheter was inserted. The first measurement showed a low cardiac index (mean $1.8 \mathrm{l} / \mathrm{m}^{2} / \mathrm{min}$ ). When compared with the left ventricular end diastolic pressure obtained during coronary angiography, the clearly lower wedge pressures reflect the unloading effect of the intra-aortic balloon pump.

In the 12 surviving patients a complete recovery of left ventricular systolic function after two weeks on average was documented by echocardiography. In two cases, a significant intraventricular pressure gradient was measured. At the time of contractile recovery the ECG normalised in four patients. In the remaining patients negative $\mathrm{T}$ waves persisted. One patient died of multiple organ failure. On necropsy, there were no macroscopic signs of recent myocardial infarction or scars. Microscopic examination showed normal myocardial tissue, except for some fatty infiltration of the left ventricular wall.

\section{Possible recurrence?}

Six years before the present admission, patient 6 had been hospitalised abroad for a similar clinical syndrome of cardiogenic shock with extensive anteroapical akinesia for which intra-aortic balloon counterpulsation was needed. Coronary angiography and left ventriculography four weeks after the acute episode were completely normal. Five months after her ventricular fibrillation with apical ballooning, patient 9 presented with vague chest complaints and deep negative $\mathrm{T}$ waves in the anterior leads. Coronary angiography was again normal, and the complaints did not recur in the following three months. We considered this episode to be "aborted" apical ballooning.

\section{DISCUSSION}

Apical ballooning: a distinct syndrome?

In 1990 and 1991 Satoh and colleagues ${ }^{2}$ and Dote and associates $^{3}$ described a syndrome consisting of an acute onset of transient extensive akinesia of the apical and mid portions of the left ventricle without significant epicardial coronary artery stenosis, accompanied by chest symptoms, ECG changes, and minimal enzymatic release. They named this syndrome "Takotsubo" shaped cardiomyopathy because of the 
resemblance of the systolic left ventricular image to the Japanese "tako tsubo" (octopus trap or pot).

As discussed below, several pathophysiological mechanisms have been hypothesised. Obviously, this constellation of signs and symptoms does not correspond to any well known pathophysiological entity. Several observations argue against a "classic" acute myocardial infarction as the underlying cause. Firstly, no significant obstruction of an epicardial coronary artery is visualised. Secondly, the akinetic zone does not correspond to the perfusion territory of a single epicardial coronary artery (fig 1). More specifically, the akinesia of the apical portion of the inferior wall extends well beyond what would be expected in the case of ischaemia in the territory of the left anterior descending coronary artery. Invariably a very large apical portion of the left ventricle is affected. Thirdly, there is a dramatic discrepancy between the extent of the akinetic zone and the very limited rise in cardiac markers. Furthermore, these patients rarely present with typical ST segment elevations on their ECG. In addition, a striking normalisation of systolic left ventricular function over a few weeks' time is observed in all survivors. Although all of these features may occur separately in a typical acute coronary syndrome, the coincidence of all of these together in the same patient drives us to regard "apical ballooning" as a distinct entity. Obviously, this does not necessarily imply that all cases have the same underlying pathophysiology. Indeed, the major variation in clinical presentation suggests differences in the underlying pathophysiological mechanisms. As discussed below, the underlying cause of this syndrome is far from elucidated, and different mechanisms may be at play in different patients with a similar clinical picture.

\section{Pathophysiology}

The observation of a normal ECG in the beginning of the disease and the development of the abnormalities described above after 4-24 hours in five of the 13 patients argues against a stenotic or a vasospastic event, in which we would expect immediate ECG changes.

The severe myocardial hypocontractility with very limited release of cardiac enzymes and complete recovery over a relatively short period of time is reminiscent of myocardial stunning. Also, the observed ECG abnormalities included symmetrical diffuse $\mathrm{T}$ wave inversion and QT prolongation, a pattern that has been associated with left ventricular stunning in unstable ischaemic syndromes. ${ }^{89}$ By definition, stunned myocardium results from prolonged postischaemic left ventricle dysfunction after brief myocardial ischaemia. ${ }^{8}$ However, in none of the patients described by Tsuchihashi and colleagues ${ }^{1}$ and in other reports, nor in the patients described herein, was there definite evidence for an obstructive or flow limiting lesion on coronary angiography performed immediately after the onset of symptoms. ${ }^{3}{ }^{10} 11$ Transient vasospasm of an epicardial coronary artery may explain this discrepancy. Arguing against this hypothesis is the observation that the area of akinesia does not correspond nicely to the perfusion territory of a single epicardial coronary artery-that is, in most patients it extends well beyond the perfusion territory of the left anterior descending artery, as well in the anterior and in the inferior portion of the left ventricle.

Multiple vasospastic angina has also been postulated to be a cause of stunned myocardium. In the series of Tsuchihashi and colleagues, ${ }^{1}$ vasospasm could be provoked in no more than 10 of 48 patients $(21 \%)$. In our series, diffuse constriction of the left anterior descending and the circumflex arteries occurred after infusion of acetylcholine $10^{-6} \mathrm{~mol} / \mathrm{l}$ in the left anterior descending artery in the only patient in whom this test was performed. Given this limited incidence of confirmed vasospasm, multiple vasospasm seems unlikely to be a main cause of this syndrome in most patients. In addition, it is not clear why multiple vasospasm would invariably afflict the same large apical portion of the left ventricle.
In the majority of cases described to date, triggering conditions that precede onset were described, consisting of exposure to internal (emotional) and external stresses (trauma, surgical procedure, exacerbation of a pre-existing condition). This suggests that enhanced sympathetic activity plays a major part in the origin of this syndrome. On the other hand, Villareal and colleagues ${ }^{10}$ observed left ventricular outflow tract (LVOT) obstruction in three patients with a similar syndrome. ${ }^{6}$ They hypothesised that patients with a sigmoid interventricular septum, small LVOT, and reduced left ventricular volumes (primarily women) and an abnormal orientation of a slack mitral apparatus have a geometrical predisposition to dynamic LVOT obstruction, which may manifest in the setting of intense adrenergic stimulation or hypovolaemia. ${ }^{10}$ With LVOT obstruction, apical and anterior wall stress and left ventricular filling pressures increase while systemic blood pressure decreases. Increased oxygen demand and reduced coronary perfusion pressure may combine to produce myocardial ischaemia, stunning, regional wall motion abnormalities, and associated T wave changes. This hypothesis may explain the female predominance in the patients presenting with this syndrome. On the other hand, only 12 of 72 patients in Tsuchihashi's series and only 2 of 13 patients in our series had a significant intraventricular pressure gradient. Patient 10 of our series needed mitral surgery seven months after her acute episode because of complaints due to mitral regurgitation and LVOT obstruction caused by systolic anterior movement of the anterior mitral leaflet in the absence of significant septal hypertrophy.

In 1986, Scully and associates ${ }^{11}$ described a similar case of a 44 year old woman who was well until she was informed that her 17 year old son had committed suicide by hanging. On endomyocardial biopsy they found necrotic myocytes with focal interstitial mononuclear cell infiltration, and antimyosin antibody cardiac scintigraphy was strongly positive. They treated the patient for myocarditis and she made an uneventful recovery over the following months.

The only endomyocardial biopsy we performed was entirely normal. Although this may well be caused by sampling error, the clinical picture in this syndrome is not suggestive of myocarditis, and a close association between intense emotional stress and sudden onset myocarditis seems most unlikely. In addition, in the one patient who died, no signs of myocarditis or myocardial necrosis were found on microscopic examination.

\section{Clinical implications}

Until now, this novel clinical syndrome had, with the exception of a few isolated cases, been described only in Japanese patients. Since it is now obvious that it also occurs in white patients, clinicians in the western world should also be aware of the existence of this syndrome. This is important because this syndrome mimicking acute myocardial infarction may inadvertently expose patients to futile administration of fibrinolytic agents. More important, we urgently need more information on the pathophysiology and optimal treatment of this syndrome. These are not necessarily the same for all patients presenting with this syndrome, since various pathophysiological mechanisms may underlie the final clinical picture. Indeed, while some of these patients have been successfully treated with $\beta$ adrenoceptor blockade, $\alpha$ adrenoceptor agonism, and volume expansion, many others have received positive inotropic agents and intra-aortic balloon counterpulsation. Since the optimal treatment of some patients presenting with this syndrome may thus be detrimental to other patients, it is of vital importance that the cardiological community gather this needed information. In addition, since recurrence of this syndrome in some patients seems possible, prompt recognition is needed. 


\section{Conclusion}

We report the first series of "apical ballooning" in white patients. This syndrome consists of an acute onset of transient extensive akinesia of the apical and mid portions of the left ventricle, without significant stenosis on the coronary angiogram, accompanied by chest symptoms, ECG changes, and a limited release of cardiac markers disproportionate to the extent of akinesia. Despite dramatic initial presentation, left ventricle function recovered completely within weeks in the survivors.

\section{Authors' affiliations}

W J R Desmet, B F M Adriaenssens, J A Y Dens, UH Gasthuisberg, Herestraat 49, 3000 Leuven, Belgium

\section{REFERENCES}

1 Tsuchihashi K, Ueshima K, Uchida T, et al. Transient left ventricular apical ballooning without coronary artery stenosis: a novel heart syndrome mimicking acute myocardial infarction. J Am Coll Cardiol 2001;38:11-8

2 Satoh $\mathrm{H}$, Tateishi $\mathrm{H}$, Uchida $\mathrm{T}$, et al. [Takotsubo type cardiomyopathy due to multivessel spasm]. In: Kodama K, Haze K, Hon M, eds. [Clinical aspect of myocardial injury: from ischemia to heart failure] (in Japanese). Tokyo: Kagakuhyouronsya, 1990:56-64.

3 Dote K, Satoh H, Tateishi $\mathrm{H}$, et al. Myocardial stunning due to simultaneous multivessels spasm: a review of five cases. J Cardiol 1991;21:201-14.

4 Ishihara M, Satoh $H$, Tateishi $H$, et al. ["Tako tsubo" type cardiomyopathy] (in Japanese with English abstract). Kokyu to Junkan 1997;45:879-85.

5 Kawikami H, Matsuoka H, Koyama Y, et al. ["Takotsubo" type cardiomyopathy due to acute myocarditis] (in Japanese with English abstract). Kokyu to Junkan 1998;46:913-7.

6 Kawai S, Suzuki H, Yamaguchi H, et al. Ampulla cardiomyopathy ("Takotsubo" cardiomyopathy): reversible left ventricular dysfunction with ST segment elevation. Jpn Circ J 2000;64:156-9.

7 Kurisu S, Satoh H, Kawagoe T, et al. Tako tsubo like ventricular dysfunction with ST segment elevation: a novel cardiac syndrome mimicking acute myocardial infarction. Am Heart J 2002;143:448-55.

8 Kloner RA. Inverted T waves: an electrocardiographic marker of stunned or hibernating myocardium in man? Circulation 1990:82:1060-1.

9 Hirota Y, Kita Y, Tsuji R, et al. Prominent negative T waves with QT prolongation indicate reperfusion injury and myocardial stunning. J Cardiol 1992:22:325-40.

10 Villareal RP, Achari A, Wilansky S, et al. Anteroapical stunning and left ventricular oufflow obstruction. Mayo Clin Proc 2001;76:79-83.

11 Scully RE, Mark EJ, McNeely BU. Case 16 1986: case records of Massachusetts General Hospital. N Engl J Med 1986;314:1240-7.

\section{IMAGES IN CARDIOLOGY}

\section{Direct percutaneous left ventricular puncture}

A 72 year old man with mechanical valves in both the mitral and aortic positions and a history of one reoperation was referred to our institution for signs of congestive heart failure and suspected valvar dysfunction. The transoesophageal Doppler showed periprosthetic mitral regurgitation that was technically unquantifiable. Under these circumstances the patient was referred to the cardiac catheterisation laboratory for haemodynamic assessment via direct left ventricular puncture. The left ventricular apex was identified with the patient in the modified left lateral decubitus position. Local anaesthetic was infiltrated down to the periosteum of the superior border of the rib at the point of maximal impulse. Then a 21 gauge needle, an introducer, and a stylet were advanced with fluoroscopic guidance toward the right second intercostal space until the left ventricular apex impulse was encountered (panels A, B). Once the left ventricle was entered the needle and stylet were withdrawn, and pressure measurements, dye curves, and ventriculography using a flexible 4 French catheter (panel C) were performed. Mitral regurgitation was found to be severe and periprosthetic in location (panel D). Surgery was subsequently performed with beneficial results.

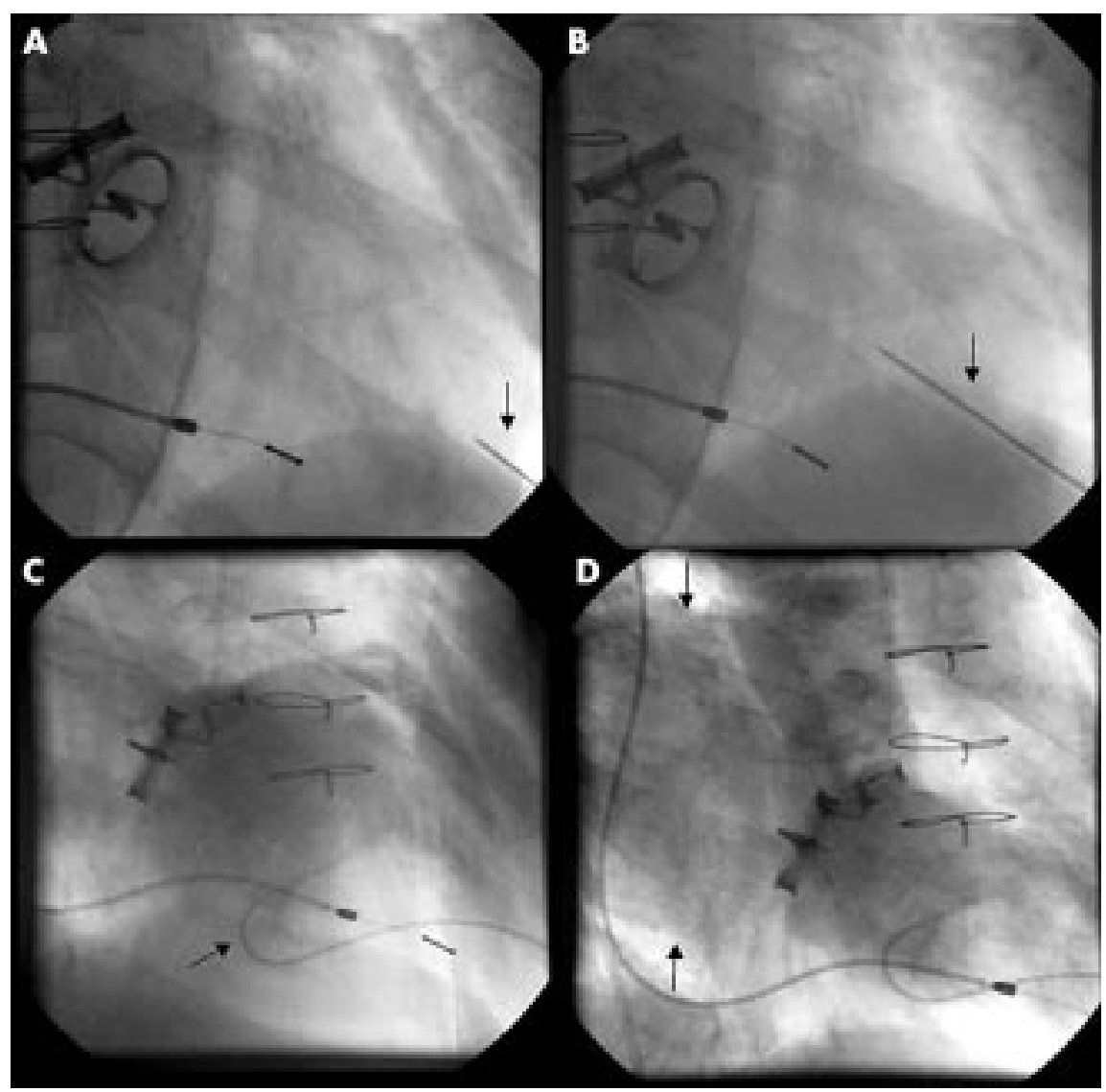

P L Sanchez E Pomerantsev I F Palacios pedrolsanchez@hotmail.com 